\title{
HIST1H3C Gene Mutation
}

National Cancer Institute

\section{Source}

National Cancer Institute. HIST1H3C Gene Mutation. NCI Thesaurus. Code C154312.

A change in the sequence of the HIST $1 \mathrm{H} 3 \mathrm{C}$ gene. 